\title{
The Timing and Nature of Human Colonization of Southeast Asia in the Late Pleistocene
}

\author{
A Rock Art Perspective
}

\author{
by Maxime Aubert, Adam Brumm, and Paul S. C. Taçon
}

\begin{abstract}
Recent technological developments in scientific dating methods and their applications to a broad range of materials have transformed our ability to accurately date rock art. These novel breakthroughs in turn are challenging and, in some instances, dramatically changing our perceptions of the timing and the nature of the development of rock art and other forms of symbolic expression in various parts of the late Pleistocene world. Here we discuss the application of these methods to the dating of rock art in Southeast Asia, with key implications for understanding the pattern of recent human evolution and dispersal outside Africa.
\end{abstract}

Rock art is the world's most widespread and long-lasting form of visual heritage and an archive of deep-time human experience. Rock art consists of paintings, drawings, stencils, prints, engravings, bas relief, and beeswax designs placed in caves and rock shelters, on boulders and rock platforms. Rock art sites are special, often spectacular places that reflect ancient human experience, identity, history, change, conflict, political viewpoints, spirituality, and relationships to land. As modern humans colonized the globe, they transformed natural landscapes into culturally meaningful places, and the worldwide distribution of rock art attests to its potency as a form of symbolic storage. This is because the creation of rock art within enduring rocky landscapes allowed ancient humans to transmit complex thought between different groups and across generations. Stories, experiences, and important events could be

Maxime Aubert is Associate Professor in the Place, Evolution and Rock Art Heritage Unit (PERAHU) of the Griffith Centre for Social and Cultural Research (GCSCR) at Griffith University (Southport, Queensland 4222, Australia [m.aubert@griffith.edu.au]) and at the Australian Research Centre for Human Evolution of the Environmental Futures Research Institute at Griffith University (Brisbane, Queensland 4111, Australia). Adam Brumm is Associate Professor in the Australian Research Centre for Human Evolution of the Environmental Futures Research Institute at Griffith University (Brisbane, Queensland 4111, Australia [a.brumm@griffith.edu.au]). Paul S. C. Taçon is ARC Laureate Fellow and Professor in the Place, Evolution and Rock Art Heritage Unit (PERAHU) of the Griffith Centre for Social and Cultural Research (GCSCR) at Griffith University (Southport, Queensland 4222, Australia [p.tacon@griffith.edu.au] and at the Australian Research Centre for Human Evolution of the Environmental Futures Research Institute at Griffith University (Brisbane, Queensland 4111, Australia). This paper was submitted 12 X 16, accepted 29 VI 17, and electronically published 15 XI 17. conveyed in new ways not solely reliant on oral history, enhancing memories and generating new interpretations in the process.

The roots of the modern human capacity to communicate using symbols likely have a long development (McBrearty and Brooks 2000; Taçon 2006; and see various references in Mellars et al. 2007) rather than resulting from a sudden, dramatic, and relatively recent evolutionary change in human cognition, as has often been argued (e.g., Klein 1989, 1992; Pfeiffer 1982; Wadley 2001). Meandering lines engraved on the surface of a bivalve shell from Trinil on the Indonesian island of Java at $\sim 500 \mathrm{ka}$ (Joordens et al. 2015), presumably the handiwork of Homo erectus, suggest that a capacity for complex abstract reasoning and symbolic thought may have existed among certain archaic and now extinct forms of humans. Concerning the latter, the apparent use of mineral pigments as colorants dates to at least 300-200 ka in both Africa (Barham 2002) and Europe (Roebroeks et al. 2012) and thus precedes the evolution of our species. Some authorities also contend that at least one now-extinct Homo lineage-Neanderthals - engaged in distinctly modern human-like patterns of symbolic activity, including the use of ochre and other pigments as colorants (e.g., Roebroeks et al. 2012); use of perforated shells (Zilhão et al. 2010), bird feathers, claws (Finlayson et al. 2012; Peresani et al. 2011), and other objects as bodily ornaments; engraving of abstract patterns on immobile rock surfaces (Rodríguez-Vidal et al. 2014); and the production of elaborate stone structures inside dark caves (Jaubert et al. 2016). Scientists are divided over the meaning of this behavior, however; indeed, the notion that even late-surviving Neanderthals had acquired elements of cognitive "modernity," either independently or through direct cultural (or genetic) contact with Homo sapiens, remains the subject of protracted debate (e.g., Langley 2013; Taçon 2010). 
Current evidence suggests that the capacity for modern human cognition and symbolic behavior emerged during the Middle Stone Age (MSA) of sub-Saharan Africa (e.g., Henshilwood, d'Errico, and Watts 2009; Henshilwood et al. 2011; Lombard 2011, 2012) and, most likely, prior to the radiation of our species from out of this continent. Ochre pieces engraved with nonfigurative imagery (mostly simple geometric patterns) have been recovered from Klasies River (d'Errico, García Moreno, and Rifkin 2012), Blombos Cave (Henshilwood, d'Errico, and Watts 2009; Henshilwood et al. 2002), and Klein Kliphuis (Mackay and Welz 2008) in deposits thought to date to $\sim 100 \mathrm{ka}, \sim 100-72 \mathrm{ka}$, and $\sim 50 \mathrm{ka}$, respectively. A paint-making "workshop" was also recovered from stratified deposits at Blombos Cave dating to $\sim 100 \mathrm{ka}$ (Henshilwood et al. 2011). Engraved ostrich eggshell fragments from Diepkloof (Texier et al. 2010, 2013), Klipdrift Shelter (Henshilwood et al. 2014), and Apollo 11 (Vogelsang et al. 2010) have been dated to $\sim 60 \mathrm{ka}, \sim 70-55 \mathrm{ka}$, and $\sim 50 \mathrm{ka}$. The earliest example of representational or "complex" art from Africa consists of stone plaques adorned with figurative depictions of animals, among other visual imagery. These objects were recovered from excavations at Apollo 11 Cave in Namibia in archaeological levels dated to $\sim 30 \mathrm{ka}$ (Jacobs et al. 2008; Vogelsang et al. 2010; Wendt 1972, 1974, 1976). With regard to other material expressions of symbolic thought - personal ornaments - shell beads from Blombos date to as early as $75 \mathrm{ka}$, while the oldest known examples of objects unmistakably modified into jewelery by modern humans (marine shell ornaments dated to $\sim 100 \mathrm{ka}$ ) were recovered from Skhul Cave and Qafzeh Cave in Israel (Bar-Yosef Mayer 2005; Bar-Yosef Mayer et al. 2009; Vanhaeren et al. 2006).

It has long been argued or tacitly assumed by many scholars that the origin of representational or complex art, especially rock art, lay outside of Africa in the deep, dark caves of Upper Paleolithic Europe (e.g., Clottes and Lewis-Williams 1998; Hodgson 2012, 2017; Lewis-Williams 2002). Research into the beginnings of art has traditionally been influenced by the idea of a creative explosion that is said to have occurred around $40 \mathrm{ka}$ among the first modern human inhabitants of Europe. For many authorities, this was a key period in human evolution during which the minds of our ancestors underwent rapid and profound changes, and a panoply of new and sophisticated forms of symbolic behavior emerged (Clottes and LewisWilliams 1998; Hodgson 2012, 2017; Klein 1989, 1992; Pfeiffer 1982). In particular, the masterful creations of the Aurignacian artists of Western Europe, such as the stunning paintings of lions, horses, and other animals in France's Chauvet Cave (37$33.5 \mathrm{ka}$; Quiles et al. 2016) and the exquisitely crafted ivory figurines ( 40-30 ka; Conard 2003) from the Swabian Alps of Germany, are viewed as pivotal milestones in the emergence of modern culture (e.g., Hodgson 2017).

As recently announced, however, new dating evidence has emerged for equally early rock art in Southeast Asia (Aubert et al. 2014; Taçon et al. 2014), challenging long-held assumptions about the emergence of the first rock art traditions. The purpose of this paper, in light of this discovery, is to consider the ways in which new forms of rock art dating are altering conventional ideas about the origin of art and symbolic expression and first appearances of the "modern" mind outside Africa. The paper consists of two parts. First, we present a detailed overview of rock art dating and how it works, providing the necessary background for our subsequent discussion of recent breakthroughs in the dating of Pleistocene art in tropical Southeast Asia, with a focus on the Sulawesi artworks. Second, we consider the implications of these findings for our understanding of the dispersal of $H$. sapiens into this region.

\section{Dating Rock Art}

There are two main groups of radiometric dating methods that can be applied to rock art: direct and indirect methods. The former implies that the archaeological item itself (the art) is directly dated. Indirect dating, however, relies on the dating of associated materials. It is therefore imperative that the relationship (i.e., the context) between the dated sample and the art is unambiguous. In some rock art studies, direct dating often involves the radiometric dating of associated materials such as secondary mineral accretions (i.e., speleothem) in direct association with the art (e.g., Aubert et al. 2014) or the sediments in which it occurs (e.g., Huyge et al. 2011). The term "direct dating" is often used to distinguish radiometric rock art dating methods from nonradiometric methods, such as the use of "diagnostic" subject matter (e.g., Akerman 1998) and superimposition of rock art styles (Walsh and Morwood 1999). This paper only refers to radiometric dating methods, and, as such, the direct dating of rock art requires that the archaeological item itself (i.e., the art) is directly dated. The dating of associated materials such as secondary mineral accretion in association with the art is known as indirect dating.

\section{Direct Dating of Rock Art}

Radiocarbon dating can in principle be applied to determine the age of organic materials present as part of the paint composition. For example, the radiocarbon dating of charcoal pigment has been used to provide age estimates for various cave paintings and drawings, with famous examples from sites across Europe such as Chauvet Cave in southern France (e.g., Quiles et al. 2016). It is always possible that charcoal pigment used by prehistoric image-makers was significantly older than the marking event that created the artwork. Hence, and despite implicit assumptions to the contrary, radiocarbon dating of charcoal pigment can only provide a maximum age for the art. There is also the added difficulty of potential contamination by other sources of carbon. These contaminating materials can, in principle, be removed by chemical pretreatments (Douka and Higham 2017). The potential mixing of charcoal of different ages, which cannot be removed by pretreatment, can also be an issue. 
Similarly, rock art images created using beeswax-wellknown motif types in some parts of northern Australia, in particular - can be directly dated with radiocarbon. These images are predominantly composed of bee-collected plant resin and a small amount of wax (Morwood, Walsh, and Watchman 2010; Taçon et al. 2004, 2010). A light pretreatment (Nelson 2000) is usually applied in order to remove nonorganic contaminants, but no pretreatment for organic contaminants can be used. The results therefore represent the total organic carbon content of the material used to create the imagery. The dating of beeswax motifs can also provide minimum and maximum ages for overlying and underlying artwork.

Organic binders or other intrusions of organic materials such as blood, fats, semen, saliva, urine, and plant juices and fibers could have been mixed with inorganic components in paints (e.g., Gillespie 1997; Loy et al. 1990; Prinsloo et al. 2013). These can potentially be radiocarbon dated, but the nature and source of the organic components must be identified. Consequently, the selected organics chosen to represent the painting event need to be separated from unrelated organic fractions. The positive identification of these organic components is quite difficult and often a matter of debate (Gillespie 1997; Loy et al. 1990; Matheson and Veall 2014; Prinsloo et al. 2013). It is sometimes possible to visually identify and physically extract organic materials such as plant fibers from paint (e.g., Watchman and Cole 1993). Organism-specific organic compounds (biomarkers) can be, in principle, identified, isolated, purified, and radiocarbon dated (e.g., Eglinton et al. 1996). Compound-specific radiocarbon analysis is a promising avenue for rock art dating. Challenges include the difficulty of obtaining adequate quantities of samples from selected fractions.

In brief, pigment layers (and associated mineral accretions; see below) are likely to contain a mixture of organic substances, each with a different radiocarbon signature. These may potentially include unrelated younger and older organic materials that could have been incorporated at or after the marking event. Furthermore, certain living organisms, such as predatory invertebrates, are known to incorporate carbon from several sources (e.g., Hågvar and Ohlson 2013; Teuten, $\mathrm{Xu}$, and Reddy 2005). These sources might be older than the marking event (Hågvar and Ohlson 2013). Total radiocarbon analysis can therefore lead to misleading age estimates for marking events. It is essential that the nature and source of these organic substances be positively identified and separated from other unrelated sources. This allows the radiocarbon age of the sample to be tied directly to its provenance, which could then be related to the marking event.

In the vast region encompassing mainland and island Southeast Asia, where the number of dated rock art sites is extremely small, direct dating of motifs has, to our knowledge, never been applied. Radiocarbon dating could potentially be applied to the numerous charcoal paintings and drawings attributed to the Austronesian expansion in the region in the Holocene (O'Connor et al. 2015).

\section{Indirect Dating of Rock Art}

The indirect dating of rock art, as described here, requires that the art be radiometrically dated by association. This can occur in the form of excavated pieces of decorated rock surfaces that have detached from overhead art panels and subsequently become incorporated into the burial matrix (e.g., David et al. 2013; Wendt 1976) or, indeed, portable artworks (art mobilier) recovered from securely dated stratigraphic contexts. Similarly, decorated rock surfaces that have been covered or partly covered over by sediments in situ can potentially be dated by association with the sedimentary deposit (e.g., Huyge et al. 2011; Rosenfeld, Horton, and Winter 1981). In the first instance, analyzing datable materials present in the sedimentary units in which the artwork was found, or immediately above, can provide a minimum age for the art. In the second instance, datable materials present at the same depth or above the artwork provide the minimum age. Datable materials include any material usually used for dating archaeological deposits, such as organic material (radiocarbon), grains of quartz and feldspars (luminescence), fossil bones and teeth (electron spin resonance and uranium series), and speleothem (uranium series). Providing accurate and reliable dates for art using these techniques relies on establishing whether the association between the datable materials and the art is genuine (e.g., ruling out the possibility of movement of older or younger sediment, vertical displacement or intrusion of art objects, and so on).

Rock surface coatings are often found in association with rock art. Some of these features may be datable or may contain datable materials. If an age estimate is obtained for mineral accretions overlying a painting or an engraving, it can provide a minimum age for the art. Similarly, an age estimate for a rock surface coating underlying a painting can provide a maximum age for the art. Examples of datable rock surface coatings often found in association with rock art include amorphous silica skins (e.g., Morwood, Walsh, and Watchman 2010), rock "desert" varnishes (e.g., Watchman 2000), oxalate-rich crusts (e.g., Morwood, Walsh, and Watchman 2010), and calcium carbonate accretions (e.g., Aubert et al. 2007, 2014; Pike et al. 2012).

Radiocarbon dating has been used to date organic materials in rock surface coatings overlying and underlying rock art. In most cases, the analyses are performed on the total organic content and, as such, face similar issues as those mentioned above for the direct dating of pigment layers (e.g., possible contamination from carbon from various sources unrelated temporally to the marking event). Moreover, the modes of formation of certain rock surface coatings such as rock desert varnishes and oxalate-rich crusts are not fully understood, making any dating attempt with radiocarbon or other methods dubious. Compound-specific carbon analysis (stable isotopes and radiocarbon) could potentially resolve questions about their modes of formation as well as providing a valuable dating method. 
There are other indirect rock art dating methods available, such as optically stimulated luminescence dating (OSL), which has been applied to mud-wasp nests associated with rock art (Roberts et al. 1997; Ross et al. 2016). However, these have never been applied in Southeast Asia and are not described here.

\section{Southeast Asia's Dated Rock Art}

Southeast Asia harbors a significant collection of prehistoric rock art, possibly spanning many tens of thousands of years of human cognitive and cultural evolution (Taçon et al. 2014). The region encompassing mainland and island Southeast Asia includes some $400,000 \mathrm{~km}^{2}$ of karst, including some of the largest limestone karst ecosystems on earth (Clements et al. 2006). Rock art is often found within these landscapes and is sometimes partly covered over by secondary calcium carbonate deposits. Rock art is also sometimes found over layers of calcium carbonate accretions or even sandwiched between them, in the latter instance providing the potential opportunity to acquire both minimum and maximum ages for associated art. Two dating methods, radiocarbon dating and uraniumseries dating, have been applied to date these calcium carbonate accretions in association with what has now been revealed as some of the most ancient surviving examples of rock art on the planet.

Calcium carbonate accretions such as flowstone (e.g., Aubert et al. 2007; Pike et al. 2012; Taçon et al. 2012) and coralloid speleothem (Aubert et al. 2014) have been found in association with rock art and can provide minimum and maximum age estimates for the art. Radiocarbon dating can be applied to calcium carbonate accretions (Plagnes et al. 2003; Taçon et al. 2012) but is considered problematic principally because of possible contamination from a range of sources of carbon (similar to the issues mentioned above) and unknown contribution from geologically "dead" carbon (Harmon and Wicks 2006). The dead carbon content in speleothem can be up to at least 38\% (Genty et al. 2001), and its contribution will result in an overestimated radiocarbon age. Therefore, obtaining reliable calendar ages with speleothem radiocarbon dating requires estimation of the fraction of dead carbon incorporated in the sample. This is usually achieved by using both uraniumseries and radiocarbon chronologies simultaneously (e.g., Genty et al. 2001). When possible, active calcium carbonate accretions can also be employed to estimate the dead carbon fraction, assuming a constant input through time. The issues related to contamination from unknown sources of carbon could also potentially be addressed by compound-specific carbon analysis.

Uranium-series disequilibrium dating is the method of choice for dating calcium carbonate accretions in association with rock art (e.g., Aubert et al. 2007, 2014; Pike et al. 2012; Plagnes et al. 2003; Taçon et al. 2012). Similar to the method mentioned above, uranium-series disequilibrium dating can provide minimum and maximum ages for individual motifs. When precipitated from saturated solutions, calcium carbonate usually contains small amounts of soluble uranium $\left({ }^{238} \mathrm{U}\right.$ and $\left.{ }^{234} \mathrm{U}\right)$ that eventually decay to ${ }^{230} \mathrm{Th}$. The latter is essentially insoluble in cave waters and will not precipitate with the calcium carbonate. This produces disequilibrium in the decay chain, whereby all isotopes in the series are no longer decaying at the same rate. Subsequently, all the isotopes in the decay chain will decay until secular equilibrium, the rate at which the thorium decays will equal the rate at which it is being produced by the decay of uranium, is reached. Because the decay rates are known, the precise measurement of these isotopes allows calculation of the age of the carbonate formation. The dating range of the uranium-series approach depends on the ability to measure isotopic ratios that are different from, but close to, equilibrium. This is based on the size of the errors, which is a function of the uranium concentrations in the sample and the detection system. Multicollector inductively coupled plasma mass spectrometry (MC-ICP-MS) measurements can be used to estimate closed system ${ }^{230} \mathrm{Th} /{ }^{234} \mathrm{U} /{ }^{238} \mathrm{U}$ ages ranging from just a couple of years up to about 600,000 years. For more information on this dating method and its applications, see Bourdon et al. (2003).

Recent improvements in uranium-series analysis enable the measurement of minute calcium carbonate samples at very high precision. These improvements now allow the measurements of minute samples in direct association with rock art. However, in order to accurately date rock art with such a technique, certain principles must be met:

1. The marking event that is being dated must be unambiguous. This principle applies to any rock art dating method whereby the art was intentionally made rather than a byproduct of some other activities. A pigment layer found sandwiched between layers of rock surface coatings with no identifiable motif is not diagnostic evidence for rock art production (e.g., Aubert et al. 2007; Watchman 1993). Similarly, a pigment layer with no identifiable motif found on a slab recovered from an excavation cannot be directly linked to rock art production (e.g., O'Connor and Fankhauser 2001). Ocherous materials occur naturally in caves and rock shelters (Aubert et al. 2007; Huntley et al. 2015; Taçon et al. 2012). Moreover, ochre was not exclusively used for creating rock art (e.g., d'Errico, García Moreno, and Rifkin 2012; Rifkin et al. 2015; Rosso, d'Errico, and Zilhão 2014; Zipkin et al. 2014).

2. The stratigraphic relationship between the dated sample and the pigment layer must be unambiguous. This principle also applies to any indirect rock art dating method. Calcium carbonate accretions are usually composed of multiple layers that have been deposited at different times. These layers can also be undulating, with their complex topography complicating attempts to precisely define their stratigraphic position in relation to the pigment layer. In Sulawesi (see below and Aubert et al. 2014), samples of coralloid speleothems overlying rock art motifs were sawn in situ so as to produce a continuous microstratigraphic profile extending from the outer surface of the coralloid through the pigment layer and into the underlying rock face or coralloid (Aubert et al. 2014; fig. 1). This sampling strategy was employed because at some locations 

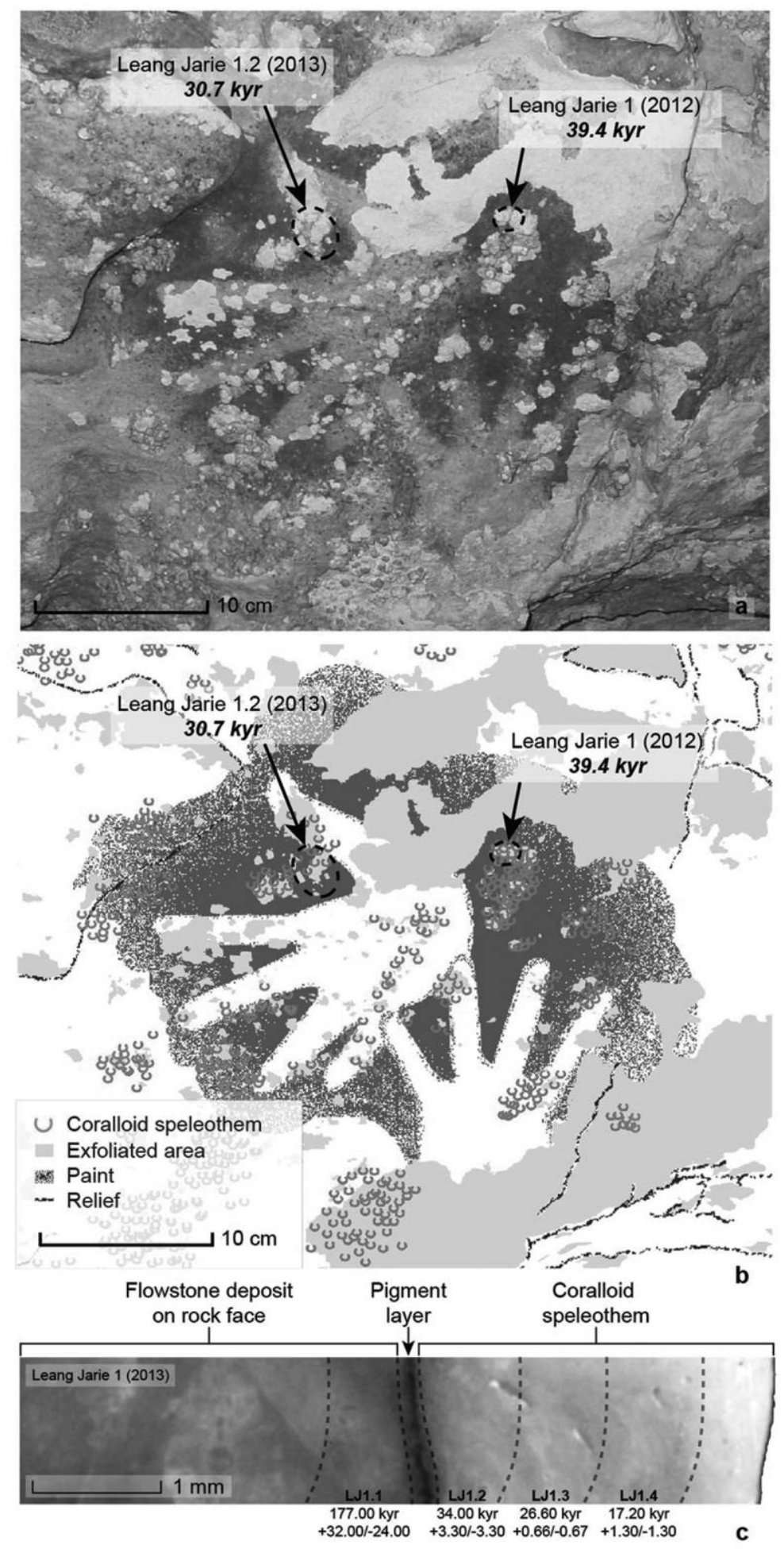

Figure 1. Dated rock art from Leang Jarie, Sulawesi, Indonesia. $a, b$, Photograph $(a)$ and tracing $(b)$ showing the locations of the dated coralloid speleothems and associated hand stencils. $c$, Profile of the coralloid speleothem Leang Jarie 1 (2013) showing the microexcavated subsamples bracketing the age of the paintings. The Leang Jarie 1 (2012) sample is from above the pigment layer and so only provides a minimum age for the underlying hand stencils. Source: Nature (Aubert et al. 2014). A color version of this figure is available online. 
pigment layers directly overlying coralloid speleothems were observed with no additional calcium carbonate accretions covering them. Coralloid speleothems were also observed where the surface had completely weathered away, making it impossible to determine from visual inspection alone if the pigment layer associated with the identifiable motif had also weathered away or if portions of it were still preserved within the microstratigraphic deposit. Therefore, analyses were carried out only on samples for which there was a directly observable continuity between the pigment layer within the accretions and an identifiable rock art motif rather than an assumed correlation. In the laboratory, these samples were subsequently microexcavated in arbitrary "spits" over the entire surface of the coralloids. The pigment layer was visible across the entire length of the sample; therefore, the calcium carbonate accretions sampled for dating could be directly related to the art. The added benefit of this sampling methodology is that it can yield minimum and maximum ages for the art.

With samples such as these, each microexcavated sample comprises an average of several calcium carbonate depositional events. As such, the calculated age will represent an average age for those events. Further, it is important to note that while the radiocarbon and uranium-series dating methods may be used on the same calcium carbonate sample, in most cases the former method cannot be used as a control for the latter (see Pike et al. 2016).

3. The dated sample must be "pure." It is common for calcium carbonate to be contaminated by detrital materials such as windblown or waterborne sediments, and this can lead to uranium-series ages that are erroneously older than the true age of the sample. This is because the detrital fraction will contribute to the overall amount of uranium-series nuclides so that the sample does not reflect a radioactive disequilibrium related to the time of carbonate formation. The effects of detrital contamination can be identified and often corrected for by measuring the activity of ${ }^{232} \mathrm{Th}$ that is solely present in the detrital fraction but which plays no part in the decay chain of uranium. The degree of detrital contamination is expressed as ${ }^{230} \mathrm{Th} /{ }^{232} \mathrm{Th}$ activity. High ${ }^{230} \mathrm{Th} /{ }^{232} \mathrm{Th}$ values $(>20)$ indicate little or no effect on the calculated age, while low values $(<20)$ indicate that a significant correction will be required (Bourdon et al. 2003). Since it is difficult to determine the exact ${ }^{230} \mathrm{Th} /{ }^{232} \mathrm{Th}$ value of the detrital component, corrections for initial ${ }^{230} \mathrm{Th}$ are usually made on the basis of the ${ }^{230} \mathrm{Th} /{ }^{232} \mathrm{Th}$ ratio for bulk Earth at secular equilibrium (.825 $\pm 50 \%)$. This is usually acceptable for samples with low- to midlevel detrital contamination $\left({ }^{230} \mathrm{Th} /{ }^{232} \mathrm{Th}>5\right)$. For samples with a high level of detrital contamination $\left({ }^{230} \mathrm{Th} /{ }^{232} \mathrm{Th}<5\right)$, the calculated age is highly dependent on the values used to correct for the detrital component.

Isochron techniques can also be used to correct for the effect of detrital contamination. Cogenetic subsamples having different amounts of contamination are analyzed, and the activity ratio of the different isotopes in each of the subsamples are plotted against each other. This enables the determination of the ${ }^{232} \mathrm{Th}$-free end-member activity ratios of ${ }^{230} \mathrm{Th} /{ }^{238} \mathrm{U}_{\text {carbonate }}$ and ${ }^{234} \mathrm{U} /{ }^{238} \mathrm{U}_{\text {carbonate }}$ (Ludwig and Titterington 1994). This strategy is difficult to apply to rock art dating, however, owing to the significant number of cogenetic subsamples required.

4. There must be a demonstration that the calcite has not undergone remobilization of uranium. A conceivable problem with the uranium-series dating method is that calcium carbonate accretions can behave as an open system for uranium, whereby the element can be leached out of the accretions or remobilized (e.g., Plagnes et al. 2003). In such instances, the calculated ages will be too old because the dating method relies on the accurate measurement of uranium versus its decay product ${ }^{230} \mathrm{Th}$. In Sulawesi, this problem was tackled by avoiding porous samples and by measuring a series of subsamples (at least three and up to six per sample; fig. 1). The ages of these subsamples were all in chronological order, confirming the integrity of the dated coralloids. If uranium had leached out of the samples, a reverse age profile would have been evident, meaning the ages would have gotten older toward the surface, where they should be younger. This strategy also provides the opportunity to apply Bayesian statistics to calculate statistical age estimates for a marking event (Douka and Higham 2017; Wood 2015).

\section{Laser Ablation Uranium-Series Dating}

It is technically possible to use laser ablation uranium-series dating (Eggins et al. 2005) to date calcium carbonate accretions in association with rock art. The method has been successfully used to date similar calcium carbonate accretions in geological contexts (e.g., Gliganic et al. 2014; fig. 2). The method has also been used to provide minimum age estimates for human remains and other osseous materials (e.g., Aubert at al. 2012; Duval et al. 2012; Grün et al. 2010).

The method can also be used to quickly access the closed system assumption required for dating calcium carbonate accretions in association with rock art. The small spot size of the laser ablation system (typically 100-200 $\mu \mathrm{m}$ spot diameters) offers several advantages over solution-based methods. Apart from the ability to demonstrate that the calcite has not undergone remobilization of uranium, it is also possible to obtain a series of cogenetic subsamples that can potentially be used to correct for the effect of detrital contamination. However, the larger analytical errors usually associated with such measurements could further complicate these corrections. Nonetheless, the spatial resolution obtained with this method allows the determination of age estimates physically closer to the pigment layer.

\section{South Sulawesi, Indonesia}

The "tower" karst region of Maros-Pangkep in southern Sulawesi contains a record of prehistoric rock art that was first reported in the scientific literature in the 1950s (van Heekeren 1952). Previously, Indonesian archaeologists had identified 

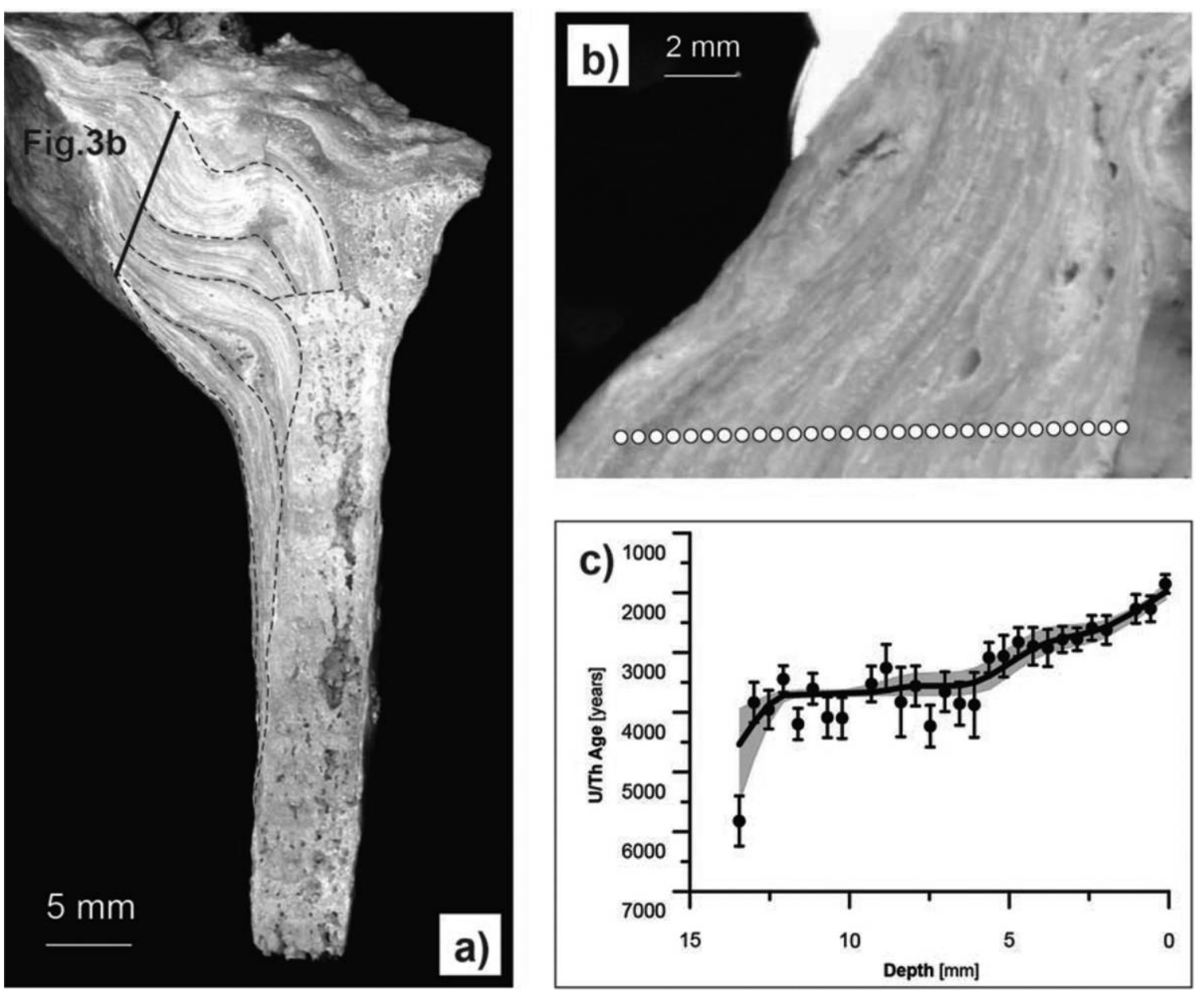

Figure 2. Mt. Chambers Gorge speleothem: (a) section of speleothem showing laminae. (b) Positions of 30 LA-ICP-MS U/Th measurements along a transect of speleothem, the position of which is shown as the black line in $a$. (c) U/Th ages (black circles) plotted against depth with the growth model (StalAge1.0) shown as black line and shading. Note that the orientation of $b$ and $c$ are the same. Dashed lines demarcate four intervals of fine laminae separated by more continuous and darker laminae. This methodology could be applied to the dating of rock art. Source: Gliganic et al. 2014. A color version of this figure is available online.

two temporally distinct phases of parietal art production based on patterns of superimposition (Eriawati 2003): the initial phase is characterized by red blown-pigment hand stencils and rare, naturalistic paintings of large mammals (predominately endemic wild boars), while the later, younger phase is dominated by black drawings of human and animal figures and a wide array of geometric signs. Until recently, it was presumed that the first phase of rock art was produced by the so-named Toaleans (Bulbeck 2004:150-151), early- to mid-Holocene hunter-gatherer communities of supposedly Mesolithic character (Bulbeck 2004; Bulbeck et al. 2000; van Heekeren 1952). None of the rock art was thought to be Pleistocene in age (but see O'Connor and Bulbeck 2013).

In an effort to establish a chronology for the extensive body of imagery known from the first phase of rock art production in Maros-Pangkep, uranium-series dating of calcium carbonate accretions overlying and underlying rock art images was recently applied to date a sample of 14 parietal motifs ( 12 hand stencils and two figurative animal paintings) from seven sites in the region (Aubert et al. 2014). The most ancient examples, a hand stencil from Leang Timpuseng, with a minimum age of 39,860 years $(40,700+870 /-840)$, and another hand stencil from Leang Jarie with a minimum age of 39,350 years $(39,670+320 /-320)$, are now the world's earliest known hand stencils. In addition, on the same rock art panel on the ceiling at Leang Timpuseng, a figurative depiction of a wild pig endemic to Sulawesi, the babirusa (Babyrousa sp.), or "pig-deer," is at least 35,400 years old $(36,900+1,600 /-1,500)$, while an incomplete and indeterminate animal figure (probably a pig) on the wall of a nearby site is at least 35,700 years old $(44,000+9,100 /-8,300)$. This is equivalent in age to what was previously considered to be the earliest two-dimensional portrayals of the animal world from France's Chauvet Cave, which are attributed to the time interval between 37,000 and 33,500 cal BP years ago (Quiles et al. 2016). The minimum and maximum age estimates obtained from Maros suggest that stenciled depictions of human hands 
were produced in this karst region, and possibly elsewhere on Sulawesi (Oktaviana et al. 2016), apparently as part of a continuous artistic tradition, for a period of at least 13,000 years (Aubert et al. 2014).

\section{East Kalimantan, Indonesia}

In the early 2000s, a French-Indonesian team reported the dating of two hand stencils from a remote karst area in northeastern Kalimantan, the Indonesian portion of Borneo (Plagnes et al. 2003). At a high-level cave site, Gua Saleh, the authors removed a large cave drapery $(\sim 50 \mathrm{~cm}$ long, $\sim 15 \mathrm{~cm}$ wide, by $\sim 1 \mathrm{~cm}$ thick) found overlaying two red-colored stencil motifs. The sample was broken into pieces, which were then analyzed for uranium-series and radiocarbon dating. Except for subsample BOR5, the results showed a discrepancy between the uranium-series and radiocarbon age estimates whereby the uranium-series ages estimates are older than the radiocarbon results. Moreover, the uranium-series age estimates are in reverse chronological order, suggesting that the cave drapery in this instance behaved as an open system for uranium. Nonetheless, sample BOR5 was located at the base of the cave drapery, and the uranium-series and radiocarbon analysis returned an age estimate of $\sim 10 \mathrm{ka}$. Cave draperies, or "curtains," are distinct and notoriously porous forms of secondary calcium carbonate deposition and are thus not ideal for uranium-series dating. Nevertheless, owing to the particular way in which these speleothems form, the base of the drapery is generally less porous and may therefore be suitable for uranium-series dating. The results from Plagnes et al.'s (2003) pioneering study suggest that red-colored hand stencils from Borneo are Pleistocene in age and are possibly older than around 10,000 years in age.

\section{Lene Hara, East Timor}

For the Gua Saleh rock art dating study, Plagnes et al. (2003) used thermal ionization mass spectrometry (TIMS) to measure the uranium-series isotopes. Because of the relatively low uranium concentrations in the samples (.057-.180 ppm) and the technology employed, large masses of samples were required (2-4 g). In the research design of the project, the decision to employ this approach may have justified the use of a large cave drapery for uranium-series dating.

Aubert et al. (2007) used, for the first time, MC-ICP-MS to date small calcium carbonate deposits in association with rock art in Timor. MC-ICP-MS requires far less uranium than TIMS, opening up new possibilities and avenues for rock art dating. Aubert et al. (2007) showed that MC-ICP-MS can be used to demonstrate a closed system for uranium for small samples of calcium carbonate deposits in direct association with rock art. The data showed that at Lene Hara Austronesianlike paintings at the surface of the flowstone were younger than $6.3 \pm .55 \mathrm{ka}$, consistent with the hypothesis that these artworks were created by early Austronesian people- the first known farmers in the Southeast Asian region. Furthermore, a red pigment lamination was identified within the calcium carbonate deposit. Although not forming a visible image, this line of red colorant in the speleothem sample was arguably part of a rock art motif. Aubert et al. (2007) bracketed the age of the red line to between $24 \pm 1.5$ and $29.3 \pm 1.2 \mathrm{ka}$, suggesting - but not demonstrating, for the reasons outlined above - an earlier phase of cave painting may have occurred at the site prior to the onset of the last glacial maximum at $\sim 22 \mathrm{ka}$.

In 2010, O'Connor and team reported the dating of newly discovered petroglyphs at Lene Hara (O’Connor et al. 2010). The petroglyphs were found on two speleothem columns (cols. A and B). As these authors observed:

A loose piece from the margin of the exfoliating layer into which the petroglyphs are carved; LH09-1-1, a powder sample drilled from the left periphery of the speleothem mass; and LH09-1-2, a sample drilled from the truncated top of the column . . . were expected to yield maximum ages for the petroglyphs on column A. (665)

The samples returned uranium-series age estimates of $36.76 \pm$ $1.3,29.4 \pm .53$, and $39.62 \pm 1.2 \mathrm{ka}$. For column B, "two samples were taken in proximity" to one of the petroglyphs and were "expected to produce a maximum age for petroglyph B1 and for the weathering of the surface." These two samples returned uranium-series age estimates of $13.72 \pm .16 \mathrm{ka}$ and $12.63 \pm .22 \mathrm{ka}$ (O’Connor et al. 2010:665). Three other samples were "taken from the edge of a relatively unweathered calcite sheet that forms the outermost layer of the column to the immediate left of petroglyph B1. As such, the calcite sheet is expected to provide a minimum age for the petroglyph" (O'Connor et al. 2010:665). These samples returned uraniumseries age estimates of $10.10 \pm .35 \mathrm{ka}, 10.17 \pm .19 \mathrm{ka}$, and $10.18 \pm .20 \mathrm{ka}$. Consequently, the authors argue that engravings were produced during the time interval between $\sim 12.5$ and $\sim 10.2 \mathrm{ka}$. If so, these images would represent the most ancient petroglyphs discovered thus far in Southeast Asia.

The petroglyph dates from Lene Hara warrant a note of caution, however. It is important to point out that the three samples taken as minimum age estimates do not directly overlay the petroglyph under study. Instead, the investigators argue that the calcite surface underlying this more recent calcite sheet showed "an equivalent degree of weathering to that affecting both the carved surface and the petroglyph itself," suggesting that deposition of the younger sampled calcite sheet "appears to have taken place after the petroglyph was carved and subsequently weathered" (O'Connor et al. 2010:656). The argument for minimum age therefore depends on a range of assumptions related to how one assesses rates or degrees of weathering in the flowstone surface (i.e., the rock art "panel"). O'Connor et al. note that the more recent calcite sheet, at apparently $\sim 10.2 \mathrm{ka}$, "shows minimal pitting," implying that most of the weathering on the carved surface and the petroglyph must have occurred rapidly (i.e., over a maximum of $\sim 2.3$ millennia) after the engraving was produced. However, 
such evaluations are invariably subjective, and there are no widely accepted criteria for quantitatively assessing the rate of weathering of engraved markings on rock surfaces, regardless of the particular substrate used.

\section{Cognitive Evolution and Early Human Migration}

As noted above, debate about the origin of modern human symbolic behavior has traditionally focused on the intensively studied record from Upper Paleolithic Europe (Belfer-Cohen and Hovers 2010; Shea 2011). Recent critiques of this Eurocentric bias, in our view, have essentially replaced it with an Africanist one (Belfer-Cohen and Hovers 2010; McBrearty 2007; McBrearty and Brooks 2000). Despite this, it is increasingly recognized that Southeast Asia is of fundamental importance to this debate in terms of the potential of the region to yield insight into the dispersal and behavioral variability of early modern human colonists (e.g., Belfer-Cohen and Hovers 2010; Brumm et al. 2017; Klein 2000; Shea 2011).

Rock art that has been directly dated using robust and reproducible scientific methods provides a potentially invaluable medium for studying cognitive evolution and Pleistocene human migration. Rock art is a form of visual expression almost exclusively associated with the presence of modern humans (despite some claims for Neanderthal rock art such as by Rodríguez-Vidal et al. 2014), and, as reviewed above, when associated with calcium carbonate accretions it can be reliably dated past the radiocarbon barrier using the uranium-series method. At present, the world's oldest surviving rock art, a red "disk" with a minimum age estimate of 40,800 years, is from El Castillo in Upper Paleolithic Spain (Pike et al. 2012) and dates to shortly after the initial arrival of our species in Western Europe ( 41,500 years ago; Higham et al. 2011). The recent rock art dates from southern Sulawesi include the hand stencil from Leang Timpuseng, which is compatible in age with the dated red disk from El Castillo. Elsewhere in Southeast Asia, we now have securely dated Pleistocene rock art at a total of seven sites on Sulawesi, where a longstanding tradition of stencil art may date back at least 40,000 years, dated Pleistocene rock art at a single cave site on the large landmass of Borneo, and possible evidence for pre-LGM rock art production in a cave on the island of Timor. So what can the oldest surviving rock art recorded in Southeast Asia, and the world, tell us about the pattern and timing of the dispersal of modern humans outside Africa?

Despite the early presence of rock art at El Castillo and the controversially old chronology inferred for the figurative animal paintings from Chauvet, prevailing wisdom holds that rock art was not significant to the colonization of Europe by Aurignacian peoples. The famous animal paintings found in decorated caves of Upper Paleolithic Europe are thought to be a predominately, though not exclusively, Magdalenian phenomenon, one that was mostly concentrated in specific parts of Western Europe (Bahn and Vertut 1997). The vast majority of known European cave art sites occur in a series of karst valleys in southwestern France and northeastern Spain-the Franco-Cantabrian region (Mellars 2009). Rock art sites of known or presumed Late Pleistocene age have been documented outside this region, such as in Italy and Britain, but these are typically isolated and separated by long distances, and in some instances the art has not been authenticated (Bahn and Vertut 1997:45). The restricted distribution of Pleistocene rock art in Europe has long puzzled archaeologists. It is sometimes proposed that rock art was concentrated in the FrancoCantabrian region owing to the large number of limestone caves in these areas of France and Spain (Bahn and Vertut 1997:200). However, other parts of Europe have extensive karstic landscapes but no dated Upper Paleolithic rock art. For instance, limestone caves in Germany's Swabian district have yielded carved animal and human figurines from Aurignacian layers (e.g., Conard 2003), but there is no parietal art of proven Pleistocene age from this region or anywhere in Germany or surrounding parts of central Europe (but see Welker 2016).

The pattern of rock art distribution in Southeast Asia appears to be broadly similar: in the island archipelago of Indonesia, for example, rock art of definite or probable Pleistocene age seems to be concentrated in specific karst regions where it is unusually abundant, such as northeastern Kalimantan (Fage and Chazine 2009; Setiawan 2014), southern Sulawesi (Aubert et al. 2014; Oktaviana et al. 2016), and the western coast of New Guinea (Arifin and Delanghe 2004; Aubert et al. 2014; Taçon et al. 2014). The quantity of rock art documented thus far in these areas, which have been only partially explored by scientists, is impressive. In the Maros karsts, for example, and the adjoining Pangkep district to the north, local cultural heritage managers have recorded at least 120 rock art sites in a tiny portion of this $\sim 450 \mathrm{~km}^{2}$ karst area. The majority of documented sites are located in the karst border plains close to modern roads and infrastructure rather than in the more remote and difficult to access areas of mountainous terrain, which, owing to their ruggedness, are yet to be systematically surveyed. Even in the most intensively studied areas close to urban settlements, new rock art sites are discovered each year. In sites with dated Pleistocene art, moreover, surviving images are often very heavily weathered; the original limestone surfaces containing rock art panels are extensively exfoliated, and in many instances only isolated patches of red paint or fragments of a hand stencil or animal painting are visible. It appears that an immense body of Pleistocene cave paintings once existed in the Maros-Pangkep landscape but is now lost, while some individual sites would have harbored extensive rock art galleries. In other parts of Indonesia, on the other hand, rock art is extremely scarce or absent in karst areas that would have offered the same geological potential for the creation of parietal art, namely, plentiful limestone rock face "canvases" in sheltered environments that were eminently suited to human habitation. Consider two of the largest islands in Indonesia, Java and Sumatra. Both are emergent landmasses on the Sunda Shelf and harbor extensive karst terrains; however, no rock art has ever been documented in the many limestone caves and shelters on Java, despite intensive searching (e.g., in the Gunung 
Sewu karsts) and despite fossil evidence for modern humans on the island by at least $37.4-28.5 \mathrm{ka}$ (Storm et al. 2013). Sumatra, roughly the same size in total land area as Spain, is larger and less densely populated than Java and has been much less comprehensively explored. However, there is still only one Sumatran site with published rock art, Gua Harimau, and the oldest motifs in this cave are more than likely of Austronesian origin (Oktaviana, Setiawan, and Saptomo 2015).

Was Pleistocene rock art formerly more uniformly distributed across the oceanic islands and continental landmasses of tropical Southeast Asia but has now survived only in isolated areas with optimal preservation conditions, or could the restricted distribution of rock art in the region constitute a real historical pattern? Were parts of Southeast Asia analogous to the Franco-Cantabrian region of Europe - special places where Pleistocene rock art cultures flourished?

Concerning the former, the Sulawesi rock art dates seem to dispel the implicit notion that faster limestone erosion rates in the humid tropics would have erased any visible evidence for rock art after only a few millennia. With regard to the latter possibility, therefore, the apparent proliferation of rock art sites in certain parts of Southeast Asia may be a reflection of other factors, such as the specific migration pathways followed by the first modern humans to enter the region as part of the colonization of Australia at 60-50 ka. It may be noteworthy, for instance, that the only sites in this region that contain rock art of known or presumed Pleistocene age fall along one of the two most likely dispersal routes from Sunda to SahulBirdsell's (1977) northern route from the easternmost edge of Sunda (Kalimantan) to Sulawesi and then to the northwestern margin of Sahul (West Papua). Following on from this, it is also conceivable that Pleistocene Southeast Asia harbored specific regions of artistic innovation that gave rise to distinct rock art traditions, centers of cultural innovation that were perhaps analogous to the Franco-Cantabrian region.

With the above points in mind, two hypotheses can be proposed to explain the presence of securely dated evidence for rock art by $\sim 40$ ka in Western Europe and Sulawesi, but thus far nowhere in between: (1) the human capacity to conceive and create rock art arose independently at roughly the same time among modern human populations in these two widely separated parts of the Pleistocene Old World; (2) rock art emerged in Africa prior to our species' dispersal from this continent and was subsequently exported throughout Pleistocene Eurasia as part of a coherent suite of modern cultural complexity, a repertoire that also included personal bodily ornaments and other material manifestations of symbolically mediated behavior. We think that of these two hypotheses the majority of scholars would regard the second as the most inherently plausible. Two further implications of this scenario can therefore be envisioned. The first is that rock art as a cultural trait was integral to the dispersal of modern humans from out of Africaperhaps, as these colonizers spread out rapidly across Eurasia, painting or otherwise decorating caves and shelters was their way of socializing new and exotic landscapes and demarcating group territories (Taçon 1994; Taçon and Brady 2016; Taçon et al. 2014). It follows that an essentially continuous trail of Pleistocene rock art may have connected Southeast Asia to both Europe and Africa - a vast record of early human symbolic expression that either has not survived along most parts of the early human migration routes or is yet to be revealed owing to a lack of intensive rock art survey in Asia and/or the difficulties of directly dating rock art. If true, this would imply that at least some parietal motifs in Western Europe currently interpreted on stylistic grounds to postdate the settlement of this region by Homo sapiens may, in future, be shown to date from the initial period of modern human colonization. The second implication is that rock art, although distinctly African in origin and extremely ancient, was not a ubiquitous component of the first modern human cultures to expand outside Africa, especially as part of the main dispersal waves that led to the colonization of Europe by $\sim 41.5 \mathrm{ka}$ and Australia by $60-50 \mathrm{ka}$; instead, Pleistocene rock art traditions arose in different places and times owing to the particular needs and histories of specific $H$. sapiens groups, including the possibility of localized increases in population density that may have driven the development and spread of complex rock art traditions (Powell, Shennan, and Thomas 2009).

Unfortunately, we presently lack the empirical evidence required to test these and other scenarios. However, following the Sulawesi rock art dating results, research is now underway (led by the first author, Aubert, with Indonesian colleagues) to determine the age of hand stencils, animal art, and other early parietal art in northeastern Kalimantan, West Papua, and adjacent areas using uranium-series dating. The wide-ranging karstic zones of eastern Borneo, Sulawesi, and western New Guinea, in particular, with their positions along likely colonization routes and abundance of prehistoric rock art, offer major potential to broaden our knowledge of a crucial period in early human prehistory.

\section{Conclusions}

Rock art is of global scientific importance, and its accurate dating is among the most challenging areas of geochronology and archaeology. As reviewed in this paper, recent technological breakthroughs now enable the accurate dating of such assemblages, advancing our knowledge of human cognitive and cultural evolution. In Southeast Asia, where the total number of Late Pleistocene archaeological sites is limited, rock art now provides a key proxy for tracing the pattern and timing of the initial peopling of the region by modern humans. It seems plausible to argue that modern humans had the capacity to make complicated rock art since they evolved in Africa, but that rock art was made at different places and times to reflect the needs of specific groups of early huntergatherers. For Southeast Asia, this seems to have occurred at least 40,000 years ago, based on evidence from Sulawesi, but as this is a minimum age from a single locality, it may have 


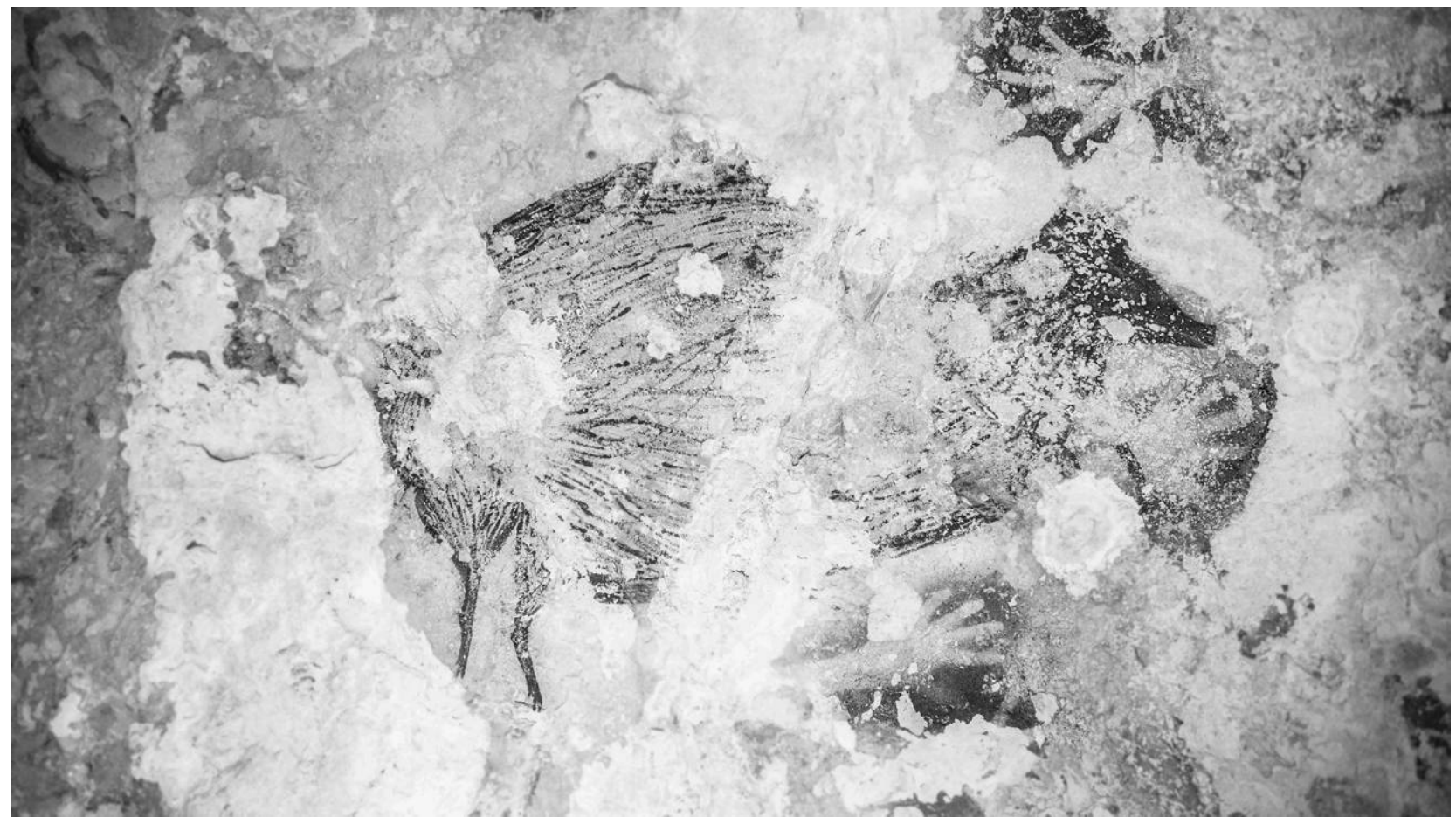

Figure 3. Large animal painting from South Sulawesi, Indonesia. The style is similar to other animal paintings from this region. Source: Kinez Riza. A color version of this figure is available online.

begun much earlier. It is also possible to speculate that a distinct rock art tradition, which perhaps arose in a specific area akin to a rock art center, moved quickly throughout the region, possibly through the northern island chain of Indonesia to Australia. A future research question to explore when new rock art dates are available is whether there was a single, continuous artistic culture rapidly moving through the island chains of Southeast Asia all the way to Pleistocene Sahul, with human hand stencils and large naturalistic paintings of animals constituting the main designs (fig. 3), or whether similar types of hunter-gatherer groups independently invented comparable forms of rock art as they colonized this region. If the former was the case, then the presence of strikingly similar kinds of rock art along a rough transect running from the easternmost edge of Asia (Kalimantan) to Sulawesi and the northern tip of Sahul (from where it stretches westward from New Guinea to the Kimberley and Arnhem Land) hints at the fundamental role that rock art played in the colonization of this region by Homo sapiens, as well as the existence of what may have been the most widespread and enduring tradition of visual culture in the history of humankind.

\section{Acknowledgments}

Aspects of this study were supported by grants from the Australian Research Council (DE140100254 and DE130101560) as well as Griffith University and the Wenner-Gren Foundation.

\section{References Cited}

Akerman, K. 1998. A rock painting, possibly of the now extinct marsupial Thylacoleo (marsupial lion), from the north Kimberley, Western Australia. The Beagle, Records of the Museum and Art Gallery of the Northern Territory 14:117-121.

Arifin, K., and P. Delanghe. 2004. Rock art in West Papua. Paris: UNESCO. Aubert, Maxime, Adam Brumm, M. Ramli, T. Sutikna, E. W. Saptomo, B. Hakim, M. J. Morwood, Gerrit D. van den Bergh, L. Kinsley, and A. Dosseto. 2014. Pleistocene cave art from Sulawesi, Indonesia. Nature 514:223-227.

Aubert, Maxime, Sue O'Connor, M. T. McCulloch, G. Mortimer, and M. Richer-LaFlèche. 2007. Uranium-series dating rock art in East Timor. Journal of Archaeological Science 34:991-996.

Aubert, Maxime, A. W. G. Pike, C. Stringer, A. Bartsiokas, L. Kinsley, S. Eggins, M. Day, and R. Grün. 2012. Confirmation of a late middle Pleistocene age for the Omo Kibish 1 cranium by direct uranium-series dating. Journal of Human Evolution 63:704-710.

Bahn, P. G., and J. Vertut. 1997. Journey through the Ice Age. London: Weidenfeld \& Nicolson.

Barham, Lawrence S. 2002. Systematic pigment use in the Middle Pleistocene of south-central Africa. Current Anthropology 43:181-190.

Bar-Yosef Mayer, D. E. 2005. The exploitation of shells as beads in the Palaeolithic and Neolithic of the Levant. Paléorient 31:176-185.

Bar-Yosef Mayer, D. E., B. Vandermeersch, and Ofer Bar-Yosef. 2009. Shells and ochre in Middle Paleolithic Qafzeh Cave, Israel: indications for modern behavior. Journal of Human Evolution 56:307-314.

Belfer-Cohen, Anna, and Erella Hovers. 2010. Modernity, enhanced working memory, and the Middle to Upper Paleolithic record in the Levant. Current Anthropology 51(suppl. 1):S167-S175.

Birdsell, J. 1977. The recalibration of a paradigm for the First People of Greater Australia. In Sunda and Sahul: prehistoric studies in Southeast Asia. J. Allen, J. Golson, and R. Jones, eds. Pp. 113-167. Toronto: Academic Press.

Bourdon, B., S. P. Turner, G. M. Henderson, and C. C. Lundstrom, eds. 2003. Uranium-series geochemistry. Reviews in Mineralogy and Geochemistry 52. Chantilly, VA: Mineralogical Society of America.

Brumm, Adam, M. C. Langley, M. W. Moore, B. Hakim, M. Ramli, I. Sumantri, B. Burhan, et al. 2017. Early human symbolic behavior in the Late Pleistocene 
of Wallacea. Proceedings of the National Academy of Sciences of the USA 114:4105-4110.

Bulbeck, D., M. Pasqua, and A. Di Lello. 2000. Culture history of the Toalean of South Sulawesi, Indonesia. Asian Perspectives 39:71-108.

Bulbeck, F. 2004. Divided in space, united in time: the Holocene prehistory of South Sulawesi. In Modern Quaternary research in Indonesia, 18. Susan G. Keates and Juliette M. Pasveer, eds. Pp. 129-166. Leiden: Balkema.

Clements, R., N. S. Sodhi, M. Schilthuizen, and P. K. L. Ng. 2006. Limestone karsts of Southeast Asia: imperiled arks of biodiversity. BioScience 56:733742.

Clottes, J., and J. D. Lewis-Williams. 1998. The shamans of prehistory: trance and magic in the painted caves. New York: Abrams.

Conard, N. J. 2003. Palaeolithic ivory sculptures from southwestern Germany and the origins of figurative art. Nature 426:830-832.

David, B., B. Barker, F. Petchey, J. J. Delannoy, J. M. Geneste, C. Rowe, M. Eccleston, L. Lamb, and R. Whear. 2013. A 28,000 year old excavated painted rock from Nawarla Gabarnmang. Journal of Archaeological Science 40:2493-2501.

d'Errico, Francesco, R. García Moreno, and R. F. Rifkin. 2012. Technological, elemental and colorimetric analysis of an engraved ochre fragment from the Middle Stone Age levels of Klasies River Cave 1, South Africa. Iourna of Archaeological Science 39:942-952.

Douka, Katerina, and Tom Higham. 2017. The chronological factor in understanding the Middle and Upper Paleolithic of Eurasia. Current Anthropology 58(suppl. 17):S480-S490.

Duval, M., C. Falguères, J.-J. Bahain, R. Grün, Q. Shao, Maxime Aubert, J.-M Dolo, et al. 2012. On the limits of using combined U-series/ESR method to date fossil teeth from two Early Pleistocene archaeological sites of the Orce area (Guadix-Baza basin, Spain). Quaternary Research 77:482-491.

Eggins, S. M., R. Grün, M. T. McCulloch, A. W. G. Pike, J. Chappell, L. Kinsley, M. Shelley, C. V. Murray-Wallace, C. Spötl, and L. Taylor. 2005. In situ U-series dating by laser-ablation multi-collector ICPMS: new prospects for Quaternary geochronology. Quaternary Science Review 24: 2523-2538.

Eglinton, T. I., L. I. Aluwihare, J. E. Bauer, E. R. M. Druffel, and A. P. McNichol. 1996. Gas chromatographic isolation of individual compound from complex matrices for radiocarbon dating. Analvtical Chemistry 68:904912.

Eriawati, Yusmaini. 2003. Lukisan di Gua-Gua Karst Maros-Pangkep, Sulawesi Selatan: Gambaran Penghuni dan Matapencahariannya. Jakarta: Indonesian Ministry of Cultural Media Development.

Fage, L. H., and J. M. Chazine. 2009. Bornéo la Mémoire des Grottes. Lyon: Fage éditions.

Finlayson, C., K. Brown, R. Blasco, J. Rosell, J. J. Negro, G. R. Bortolotti, G. Finlayson, et al. 2012. Birds of a feather: Neanderthal exploitation of raptors and corvids. PLOS ONE 7:e45927.

Genty, D., A. Baker, M. Massault, C. Proctor, M. Gilmour, E. Pons-Branchu, and B. Hamelin. 2001. Dead carbon in stalagmites: carbonate bedrock paleodissolution vs. ageing of soil organic matter: implications for C-13 variations in speleothems. Geochimica et Cosmochimica Acta 65:34433457.

Gillespie, R. 1997. On human blood, rock art and calcium oxalate: further studies on organic carbon content and radiocarbon age of materials relating to Australian rock art. Antiquity 71:430-437.

Gliganic, L. A., T. J. Cohen, J.-H. May, G. C. Nanson, A. Dosseto, J. D. Jansen, J. R. Larsen, and Maxime Aubert. 2014. Late Holocene hydrologic and environmental variability along the eastern Flinders Ranges. Holocene 24:104-117

Grün, R., Maxime Aubert, J. Hellstrom, and M. Duval. 2010. The challenge of direct dating old human fossils. Ouaternary International 234:87-93.

Hågvar, S., and M. Ohlson. 2013. Ancient carbon from a melting glacier gives high ${ }^{14} \mathrm{C}$ age in living pioneer invertebrates. Scientific Reports 3:2820.

Harmon, R. S., and C. M. Wicks, eds. 2006. Perspectives on karst geomorphology, hydrology, and geochemistry: a tribute volume to Derek C. Ford and William B. White. Special Paper 404. Boulder, CO: Geological Society of America.

Henshilwood, C. S., Francesco d'Errico, K. L. van Niekerk, Y. Coquinot, Z. Jacobs, S.-E. Lauritzen, M. Menu, and R. García-Moreno. 2011. A 100,000 year-old ochre-processing workshop at Blombos Cave, South Africa. Science 334:219-222.

Henshilwood, C. S., Francesco d'Errico, and I. Watts. 2009. Engraved ochres from the Middle Stone Age levels at Blombos Cave, South Africa. Iournal of Human Evolution 57:27-47.
Henshilwood, C. S., Francesco d'Errico, R. Yates, Z. Jacobs, C. Tribolo, G. A. T. Duller, N. Mercier, et al. 2002. Emergence of modern human behavior: Middle Stone Age engravings from South Africa. Science 295:1278-1280.

Henshilwood, C. S., K. L. van Niekerk, S. Wurz, A. Delagnes, S. J. Armitage, R. F. Rifkin, K. Douze, et al. 2014. Klipdrift Shelter, Southern Cape, South Africa: preliminary report on the Howiesons Poort layers. Lournal of Archaeological Science 45:284-303.

Higham, Tom. 2011. European middle and upper Palaeolithic radiocarbon dates are often older than they look: problems with previous dates and some remedies. Antiauity 85:235-249.

Hodgson, D. 2012. Emanations of the mind: Upper Paleolithic art as a visual phenomenon. Time and Mind 5:185-194.

. 2017. Costly signalling, the arts, archaeology and human behaviour. World Archaeology, doi: 10.1080/00438243.2017.1281757.

Huntley, J., Maxime Aubert, J. Ross, and M. Morwood. 2015. One colour, two minerals: a study of Mulberry rock art pigment and a Mulberry pigment "quarry" from the Kimberley, Northern Australia. Archaeometry 57: 77-99.

Huyge, D., D. A. G. Vandenberghe, M. De Dapper, F. Mees, W. Claes, and J. C. Darnell. 2011. First evidence of Pleistocene rock art in North Africa: securing the age of the Qurta petroglyphs (Egypt) through OSL dating. Antiauity 85:1184-1193.

Jacobs, Z., R. G. Roberts, R. F. Galbraith, H. J. Deacon, R. Grün, A. Mackay, P. Mitchell, R. Vogelsang, and L. Wadley. 2008. Ages for the Middle Stone Age of southern Africa: implications for human behaviour and dispersal. Science 322:733-735.

Jaubert, J., S. Verheyden, D. Genty, M. Soulier, H. Cheng, D. Blamart, C. Burlet, et al. 2016. Early Neanderthal constructions deep in Bruniquel Cave in southwestern France. Nature 534:111-114.

Joordens, J. C., Francesco d’Errico, F. P. Wesselingh, S. Munro, J. De Vos, J. Wallinga, et al. 2015. Homo erectus at Trinil on Java used shells for tool production and engraving. Nature 518:228-231.

Klein, R. G. 1989. Perspectives on modern human origins in southern Africa. In The human revolution: behavioural and biological perspectives on the origins of modern humans. P. Mellars and C. Stringer, eds. Pp. 529-546. Edinburgh: Edinburgh University Press.

- 1992. The archaeology of modern human origins. Evolutionary Anthropology 1:5-14.

2000. Archeology and the evolution of human behavior. Evolutionary Anthropology 9:17-36.

Langley, M. C. 2013. Storied landscapes makes us (modern) human: landscape socialisation in the Palaeolithic and consequences for the archaeological record. Journal of Anthropological Archaeology 32:614-629.

Lewis-Williams, J. D. 2002. Mind in the cave: consciousness and the origins of art. London: Thames \& Hudson.

Lombard, M. 2011. Quartz-tipped arrows older than 60 ka: further use-trace evidence from Sibudu, KwaZulu-Natal, South Africa. Journal of Archaeological Science 38:1918-1930.

- 2012. Thinking through the Middle Stone Age of sub-Saharan Africa. Ouaternary International 270:140-155.

Loy, T. H., R. Jones, D. E. Nelson, B. Meehan, J. Vogel, J. Southon, and R. Cosgrove. 1990. Accelerator radiocarbon dating of human blood proteins in pigments from Late Pleistocene art sites in Australia. Antiauity 64:110116.

Ludwig, K. R., and D. M. Titterington. 1994. Calculation of ${ }^{230} \mathrm{Th} / \mathrm{U}$ isochrons, ages and errors. Geochimica et Cosmochimica Acta 58:5031-5041.

Mackay, A., and A. Welz. 2008. Engraved ochre from a Middle Stone Age context at Klein Kliphuis in the Western Cape of South Africa. Lournal of Archaeological Science 35:1521-1532.

Matheson, C. D., and M. A. Veall. 2014. Presumptive blood test using Hemastix $^{\circ}$ with EDTA in archaeology. Iournal of Archaeological Science 41:230-241.

McBrearty, S. 2007. Down with the revolution. In Rethinking the human revolution. Paul Mellars, Katie Boyle, Ofer Bar-Yosef, and Chris Stringer, eds. Pp. 133-151. Cambridge: McDonald Institute for Archaeological Research

McBrearty, S., and A. S. Brooks. 2000. The revolution that wasn't: a new interpretation of the origin of modern human behavior. Lournal of Human Evolution 39:453-563.

Mellars, Paul. 2009. Cognition and climate: why is Upper Palaeolithic cave art almost confined to the Franco-Cantabrian region? In Becoming human: innovation in prehistoric material and spiritual culture. Colin Renfrew and Iain Morley, eds. Pp. 212-234. Cambridge: Cambridge University Press. 
Mellars, Paul, Katie Boyle, Ofer Bar-Yosef, and Chris Stringer. 2007. Rethinking the human revolution. Cambridge: McDonald Institute for Archaeological Research.

Morwood, M. J., G. L. Walsh, and A. Watchman. 2010. AMS radiocarbon ages for beeswax and charcoal pigments in north Kimberley rock art. Rock Art Research 27:3-8.

Nelson, D. E., ed. 2000. The beeswax art of Northern Australia. [CD ROM]. Burnaby: Simon Fraser University.

O'Connor, Sue, K. Aplin, E. S. Pierre, and Y.-X. Feng. 2010. Faces of the ancestors revealed: discovery and dating of a Pleistocene-age petroglyph in Lene Hara Cave, East Timor. Antiquity 84:649-665.

O'Connor, Sue, and F. Bulbeck. 2013. Homo sapiens societies in Indonesia and South-Eastern Asia. In Oxford handbooks online: scholarly research reviews. Pp. 1-12. Oxford: Oxford University Press.

O'Connor, Sue, and B. Fankhauser. 2001. Art at 40000 bp? one step closer: an ochre covered rock from Carpenter's Gap Shelter 1, Kimberley region, Western Australia. In Histories of old ages: essays in honour of Rhys Jones. A. Anderson, L. Lilley, and Sue O’Connor, eds. Pp. 287-300. Canberra: Pandanus Books, Australian National University.

O'Connor, Sue, Julien Louys, Shimona Kealy, and Mahirta. 2015. First record of painted rock art in Kupang, West Timor, Indonesia and the origins and distribution of the Austronesian Painting Tradition. Rock Art Research 32:193-201.

Oktaviana, A. A., D. Bulbeck, Sue O’Connor, B. Hakim, Suryatmanc, U. P. Wibowo, E. St Pierre, and Fakhric. 2016. Hand stencils with and withou narrowed fingers at two new rock art sites in Sulawesi, Indonesia. Rock Art Research 33:32-48.

Oktaviana, A. A., P. Setiawan, and E. W. Saptomo. 2015. Pola seni cadas (rock art) di situs Gua Harimau, Sumatra selatan. In Gua Harimau dan Perjalanan Panjang Peradaban OKU. T. Simanjuntak, ed. Pp. 149-157. Yogyakarta: Gadjah Mada University Press.

Peresani, M., I. Fiore, M. Gala, M. Romandini, and A. Tagliacozzo. 2011. Late Neanderthals and the intentional removal of feathers as evidenced from bird bone taphonomy at Fumane Cave 44 ky B.P., Italy. Proceedings of the National Academy of Sciences of the USA 108:3888-3893.

Pfeiffer, J. E. 1982. The creative explosion: an inquiry into the origins of art and religion. Ithaca, NY: Cornell University Press.

Pike, A. W. G., D. L. Hoffmann, M. García-Diez, P. B. Pettitt, J. Alcolea, R. De Balbín, C. González-Sainz, et al. 2012. U-series dating of Paleolithic art in 11 caves in Spain. Science 336:1409-1413.

Pike, A. W. G., D. L. Hoffmann, P. B. Pettitt, M. García-Diez, and J. Zilhão 2016. Dating Palaeolithic cave art: why U-Th is the way to go. Quaternary International 432, pt. B:41-49, doi:10.1016/j.quaint.2015.12.013.

Plagnes, V., C. Causse, M. Fontugne, H. Valladas, J. M. Chazine, and L. H. Fage. 2003. Cross dating $\left(\mathrm{Th} / \mathrm{U}_{-}{ }^{14} \mathrm{C}\right)$ of calcite covering prehistoric paintings in Borneo. Quaternary Research 60:172-179.

Powell, A., S. Shennan, and M. G. Thomas. 2009. Late Pleistocene demography and the appearance of modern human behavior. Science 324:12981301 .

Prinsloo, L., A. Tournié, P. Colomban, C. Paris, and S. T. Bassett. 2013. In search of the optimum Raman/IR signatures of potential ingredients used in San/Bushman rock art paint. Journal of Archaeological Science 40:29812990.

Quiles, A., H. Valladas, H. Bocherens, E. Delque-Količ, E. Kaltnecker, J. Van Der Plicht, J.-J. Delannoy, et al. 2016. A high-precision chronological model for the decorated Upper Paleolithic cave of Chauvet-Pont d'Arc, Ardèche, France. Proceedings of the National Academy of Sciences of the USA 113:46704675.

Rifkin, R. F., L. Dayet, A. Queffelec, B. Summers, M. Lategan, and Francesco d'Errico. 2015. Evaluating the photoprotective effects of ochre on human skin by in vivo SPF assessment: implications for human evolution, adaptation and dispersal. PLoS ONE 10(9):e0136090, doi:10.1371/journal.pone .0136090 .

Roberts, R., G. L. Walsh, A. Murray, J. Olley, R. Jones, M. J. Morwood, C. Tuniz, et al. 1997. Luminescence dating of rock art and past environments using mud-wasp nests in northern Australia. Nature 387:696-699.

Rodríguez-Vidal, J., Francesco d'Errico, F. Giles Pacheco, R. Blasco, J. Rosell, R. P. Jennings, A. Queffelec, et al. 2014. A rock engraving made by Neanderthals in Gibraltar. Proceedings of the National Academy of Sciences of the USA 111:13301-13306.

Roebroeks, W., M. J. Sier, T. Kellberg Nielsen, D. de Loecker, J. Parés, C. Arps, and H. Mücher. 2012. Use of red ochre by early Neanderthals. Proceedings of the National Academy of Sciences of the USA 109:1889-1894.
Rosenfeld, A., D. Horton, and J. Winter. 1981. Early man in North Queensland: art and archaeology in the Laura Area. Terra Australis 6. Canberra: Department of Prehistory, Research School of Pacific Studies, Australian National University.

Ross, J. R., K. E. Westaway, M. Travers, M. J. Morwood, and J. Hayward. 2016. Into the past: a step towards a robust Kimberley Rock art chronology. PLoS ONE 11(8):e0161726, doi:10.1371/journal.pone.0161726.

Rosso, Daniela Eugenia, Francesco d'Errico, and João Zilhão. 2014. Stratigraphic and spatial distribution of ochre and ochre processing tools at Porc-Epic Cave, Dire Dawa, Ethiopia. Quaternary International 343:85-99.

Setiawan, P. 2014. Prehistoric Kalimantan rock art as a visual study. In Rock art studies, vol. 1 of Concepts, methodology, context, documentation and conservation. B. L. Malla, ed. Pp. 73-86. New Delhi: Aryan.

Shea, John J. 2011. Homo sapiens is as Homo sapiens was: behavioral variability versus "behavioral modernity" in Paleolithic archaeology. Current Anthropology 52:1-35.

Storm, P., R. Grün, C. Stringer, A. Bartsiokas, J. de Vos, Maxime Aubert, and L. Kinsley. 2013. New dates for "Wajak Man" (Java, Indonesia) suggest a Late Pleistocene age. Journal of Human Evolution 64:356-365.

Taçon, Paul S. C. 1994. Socialising landscapes: the long term implications of signs, symbols and marks on the land. Archaeology in Oceania 29:117-129.

. 2006. Behaviorally modern at 300,000 BP: was my ancestor brighter than yours? Before Farming 2:1-9.

2010. Neanderthals and us: conflicting new interpretations on our relationship to each other. Before Farming 2010(3):1-10.

Taçon, Paul S. C., Maxime Aubert, G. Li, D. Yang, H. Liu, S. K. May, S. Fallon, X. Ji, D. Curnoe, and A. I. R. Herries. 2012. Uranium-series age estimates for rock art in southwest China. Journal of Archaeological Science 39:492-499.

Taçon, Paul S. C., and L. Brady. 2016. The place of rock art in the contemporary world. In Relating to rock art in the contemporary world: navigating symbolism, meaning and significance. L. Brady and Paul S. C. Taçon, eds. Pp. 3-13. Boulder: University Press of Colorado.

Taçon, Paul S. C., S. K. May, S. J. Fallon, M. Travers, D. Wesley, and R. Lamilami. 2010. A minimum age for early depictions of Southeast Asian praus in the rock art of Arnhem Land, Northern Territory. Australian Archaeology 71:1-10.

Taçon, Paul S. C., E. Nelson, C. Chippindale, and G. Chaloupka. 2004. The beeswax rock art of the Northern Territory: direct dating results and a "book of record." Rock Art Research 21:155-160.

Taçon, Paul S. C., N. H. Tan, S. O'Connor, J. Xueping, L. Gang, D. Curnoe, D. Bulbeck, et al. 2014. The global implications of the early surviving rock art of greater Southeast Asia. Antiquity 88:1050-1064.

Teuten E. L., L. Xu, and C. M. Reddy. 2005. Two abundant bioaccumulated halogenated compounds are natural products. Science 307:917-920.

Texier, P.-J., G. Porraz, J. Parkington, J.-P. Rigaud, C. Poggenpoel, C. Miller, C. Tribolo, et al. 2010. A Howiesons Poort tradition of engraving ostrich eggshell containers dated to 60,000 years ago at Diepkloof Rock Shelter, South Africa. Proceedings of the National Academy of Sciences of the USA 107:6180-6185.

Texier, P.-J., G. Porraz, J. Parkington, J.-P. Rigaud, C. Poggenpoel, and C. Tribolo. 2013. The context, form and significance of the MSA engraved ostrich eggshell collection from Diepkloof Rock Shelter, Western Cape, South Africa. Iournal of Archaeological Science 40:3412-3431.

Vanhaeren, M., Francesco d'Errico, C. Stringer, S. L. James, J. A. Todd, and H. K. Mienis. 2006. Middle Paleolithic shell beads in Israel and Algeria. Science 312:1785-1788.

van Heekeren, H. R. 1952. Rock-paintings and other prehistoric discoveries near Maros (South West Celebes). Laporan Tahunan Dinas Purbakala 1950:22-35.

Vogelsang, R., J. Richter, A. Jacobs, B. Eichhorn, V. Linseele, and R. G. Roberts. 2010. New excavations of Middle Stone Age deposits at Apollo 11 rock shelter, Namibia: stratigraphy, archaeology, chronology and past environments. Journal of African Archaeology 8:185-218.

Wadley, L. 2001. What is cultural modernity? a general view and a South African perspective from Rose Cottage Cave. Cambridge Archaeological Journal 11:201-221.

Walsh, G. L., and M. J. Morwood. 1999. Spear and spearthrower evolution in the Kimberley region, N.W. Australia: evidence from rock art. Archaeology in Oceania 34:45-59.

Watchman, A. L. 1993. Evidence of a 25,000 year old pictograph in northern Australia. Geoarchaeology 8:465-473.

. 2000. A review of the history of rock varnish dating. Earth Science Reviews 49:261-277. 
Watchman, A., and N. Cole. 1993. Accelerator radio-carbon dating of plantfibre binders in rock paintings from northeastern Australia. Antiauity 67:355-358.

Welker, W. 2016. First Palaeolithic rock art in Germany: engravings on Hunsrück slate. Antiquity 90:32-47.

Wendt, W. E. 1972. Preliminary report on an archaeological research programme in South West Africa. Cimbebasia B 2:1-61.

- 1974. "Art mobilier" aus der Apollo 11-Grotte in Südwest-Afrika. Acta Praehistorica et Archaeologica 5:1-42.

1976. Art mobilier from the Apollo 11 Cave, South West Africa: Africa's oldest dated works of art. South African Archaeological Bulletin 31:5-11.
Wood, R. 2015. From revolution to convention: the past, present and future of radiocarbon dating. Lournal of Archaeological Science 56:6172.

Zilhão, João, D. E. Angelucci, E. Badal-García, Francesco d'Errico, F. Daniel, L. Dayet, Katerina Douka, et al. 2010. Symbolic use of marine shells and mineral pigments by Iberian Neandertals. Proceedings of the National Academy of Sciences of the USA 107:1023-1028.

Zipkin, A. M., M. Wagner, K. McGrath, A. S. Brooks, and P. W. Lucas. 2014 An experimental study of hafting adhesives and the implications for compound tool technology. PLoS ONE 9(11):e112560, doi:10.1371/journal.pone .0112560 . 